\title{
The Climate Change Impacts on Water Resources and Crop Yield
}

\author{
Sorush Niknamian* \\ Department of Cell and Molecular Biology, Liberty University, USA
}

Submission: August 10, 2019; Published: August 26, 2019

*Corresponding author: Sorush Niknamian, Department of Cell and Molecular Biology, Liberty University, United States of America

\begin{abstract}
This research evaluated climate change impacts on temperature, precipitation, and runoff using LARS-WG and SWAT models under climate scenarios. First, drought intensity was calculated for the period 1987-2016. Then, the LARS-WG model was calibrated to generate climatological data for future periods. The coefficients of precipitation as well as minimum and maximum temperature changes were simulated as SWAT model inputs. The results of LARS-WG model indicated that temperature will increase in future periods and that changes will occur not only in precipitation rate but also in its pattern. Then, changes in runoff were simulated by introducing downscaled results to SWAT model. The model was calibrated and validated by SWAT-CUP software. Nash-Sutcliffe (NS) coefficients (0.58 and 0.49) and R2 determination coefficients ( 0.65 and 0.50$)$ were obtained for calibration and validation periods, respectively. The results showed that runoff will increase in spring and summer during 2011-2030 period, but it will decrease in fall and winter. Further, runoff will rise in fall and winter while it will drop in spring and summer throughout 2046-2065 and 2080-2099 periods under all three scenarios. Such seasonal shifts in runoff levels result from climate change consequences in the forms of temperature rise, snowmelt, altered precipitation pattern, etc. Future-period evapotranspiration will rise under all three scenarios with a maximum increase in 2080-2099 period under A2 scenario. Additionally, rainfed crop yields will decline without considerable changes in irrigated and horticultural crop yields.
\end{abstract}

Keywords: Climate change; SPI index; LARS-WG model; Runoff; SWAT model

\section{Introduction}

Iran is considered among arid and semi-arid areas in the global climatic zonation [1]. Evidence from historic climatological data as well as forecasts of Iran's climatic conditions, as elsewhere worldwide, indicate incidence of climate change in recent decades with an ongoing trend in the future. One of the consequences of climate change is the occurrence of drought in the region. Harmsen et al. [2] measured the temperature and precipitation data in Puerto Rico using the DOE / NCR PCM general circulation model under the three scenarios A1, B1, and A2. They believed that the in the rainfall season, it would be humid while it is projected to be dry in the dry season. They also showed that evapotranspiration would also increase in dry days by reducing rainfall and increasing the temperature. Alipour et al. [3], in three central provinces of Iran, using 30-year precipitation data at 20 weather stations, showed that SPI index is more flexible in drought analysis on monthly, seasonal and annual time scales compared to other methods. It shows itself.

Climatic alterations will also seriously affect water resources, with a vast domain of including surface waters, ground waters, and water-related constructions experiencing considerable consequences. Simulation by hydrological, general circulation, and regional climate models are among methods for the study of climate change impacts on water resources. General circulation and regional climate models are available tools for global climate simulation, the outputs (e.g., temperature and precipitation) of which are applied as inputs of hydrological models, thereby assessing climate change effects on the hydrological cycle [4]. Ficklin et al. [5] conducted a study on climate change effects on basin runoff using SWAT model and LARS-WG software in order to investigate sediment load, nitrate, phosphate, and agricultural fertilizer residues affected by climate change in San Joaquin watershed, California, downscaled by LARS-WG for 2100 period. Through Special Report on Emission Scenarios (SRES) with regards to $\mathrm{CO}_{2}$ emissions by agricultural practices, they found that the rising levels of this pollutant would result in $23 \%$ drop in runoff and $2{ }^{\circ} \mathrm{C}$ increase in temperature. Devkota \& Gyawali [6] employed SWAT model for hydrological simulation in order to investigate climate change effects on the management of areas and hydrological water resources at Kushi River basin in Nepal. Their results suggested that climate change was not a large threat to the water available in that area. Nevertheless, the projected flow for the return period was strongly dependent on climate change in implementing the climate model. Elsewhere, climate change and 
land use impacts on the runoff and water resources in part of Lordegan basin were predicted by SWAT model [7]. Climate changes in near (2011-2039), middle (2040-2069), and far (2070-2099) futures were studied based on CRU downscaled data obtained from HadCM3 model output as well as projected $\mathrm{CO}_{2}$ concentration both under A2 emission scenario. The percentage of rainfall changes and mean monthly temperature were then calculated and incorporated into optimized first and second models. SWAT model presented an acceptable accuracy in both calibration and validation phases. They further found that negative consequences arisen from climate change would be more drastic in future periods. Shrestha et al. [8] applied LARS-WG and SWAT models to study the climate change-related runoff and sediment uncertainty in future periods of 2030 and 2060 under GCM model. They reported increased sediment load and reduced runoff in the future. The influences of climate changes on surface water resources in Pangani basin were assessed by SWAT and WEAP models [9]. The results indicated $10 \%$ rise in the runoff and almost $2{ }^{\circ} \mathrm{C}$ elevation in temperature during the 2050 s compared to the baseline period. Irrigation was also predicted to undergo a severe shortage necessitating urgent and future planning for water use. Zhou et al. [10] assessed the quantitative effects of climate change and anthropogenic activities on runoff fluctuations in Dongjiang River basin, China, and detected elevated annual temperature and declined evaporation rate. SWAT model also displayed an acceptable performance. Furthermore, climate change impacts (58\%) proved to be slightly greater than those of anthropogenic activities (42\%) in the whole basin. Yin et al. [11] employed the climate models of CMIP5 and SWAT to investigate climate change effects on Jinsha River flow. They discovered a drop in the runoff by $2-5 \%$ as a result of $1{ }^{\circ} \mathrm{C}$ temperature rise, with $0.5-0.8 \%$ decrease in precipitation and $1.31-1.87^{\circ} \mathrm{C}$ elevation in temperature. Using SWAT model, the impact of climate change on rice yield was studied in Nanliujiang basin, China, suggesting a high ability of SWAT model in simulating the studied basin. Rice yield increased from $1.4 \%$ to $10.6 \%$ under GFDL-ESM2M and IPSL-CM5A-LR climate models while HadGEM2-ES model resulted in diminishes yield (Yang et al., 2018). In Awash basin, Ethiopia, Daba [12] conducted a study on runoff sensitivity to temperature and precipitation. They observed a high runoff sensitivity to both variables, such that annual temperature rises of $1,2,3,4$ and $5{ }^{\circ} \mathrm{C}$ leads to annual runoff reductions to $-0.085,-0.88,-1.75,-2.55$, and $-3.30 \%$, respectively. Al Qatarneh et al. [13] used SWAT model to study climate change impacts on water resources in Jordan and reported elevated air temperature. However, according to them, no changes occurred in the annual precipitation trend. In a study on evaluation of climate change impact on Kan basin runoff [14], temperature and precipitation variables were simulated by data from the large-scale model HadCM3 under A2 scenario and SDSM downscaling model. The runoff was simulated monthly by SWAT hydrological model. The results indicated falling precipitations and rising temperatures across all selected stations. The developed climate scenarios finally demonstrated ascending and descending runoff levels in winter and other seasons, respectively.

Given different climate changes around the world, Iran cannot be excluded from these large-scale changes, the consequences of which are observed in many Iranian basins. The present study, therefore, evaluated climate change impact on the runoff in Varamin plain basin using LARS-WG and SWAT models under A1B, $\mathrm{A} 2$, and $\mathrm{B} 1$ emission scenarios.

\section{Materials and Methods}

\section{Study area}

This study was conducted on Salt Lake sub-basins viz. Lavasanat, Damavand, and Varamin plain basins located at $35^{\circ} 0^{\prime} 0^{\prime \prime}$ to $36^{\circ} 0^{\prime} 0^{\prime \prime} \mathrm{N}$ latitude and $51^{\circ} 0^{\prime} 0^{\prime \prime}$ to $52^{\circ} 0^{\prime} 0$ " E longitude (Figure $1 \& 2$ ).

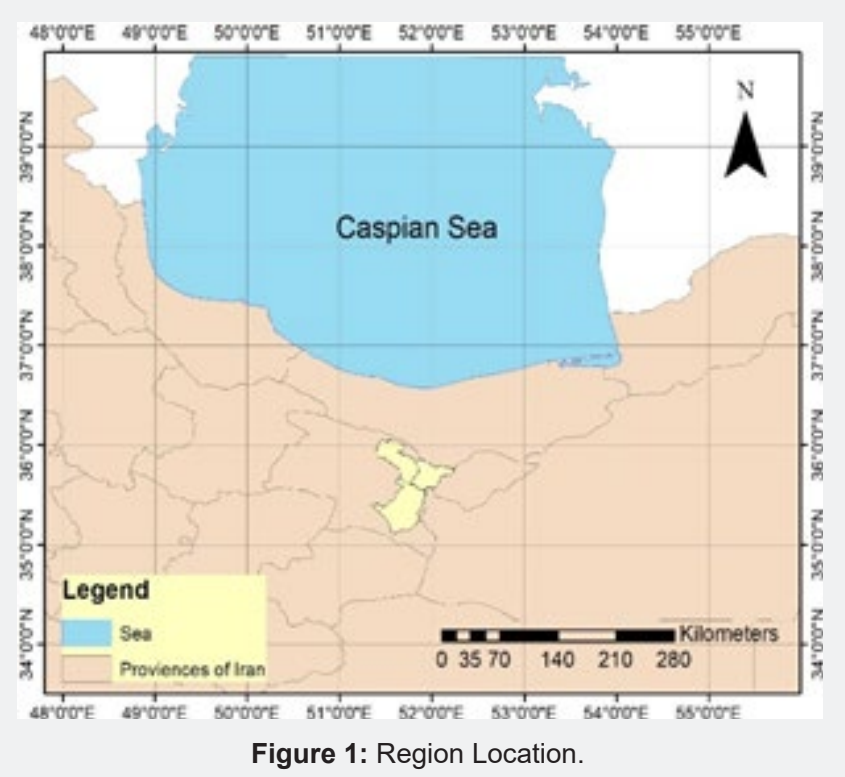




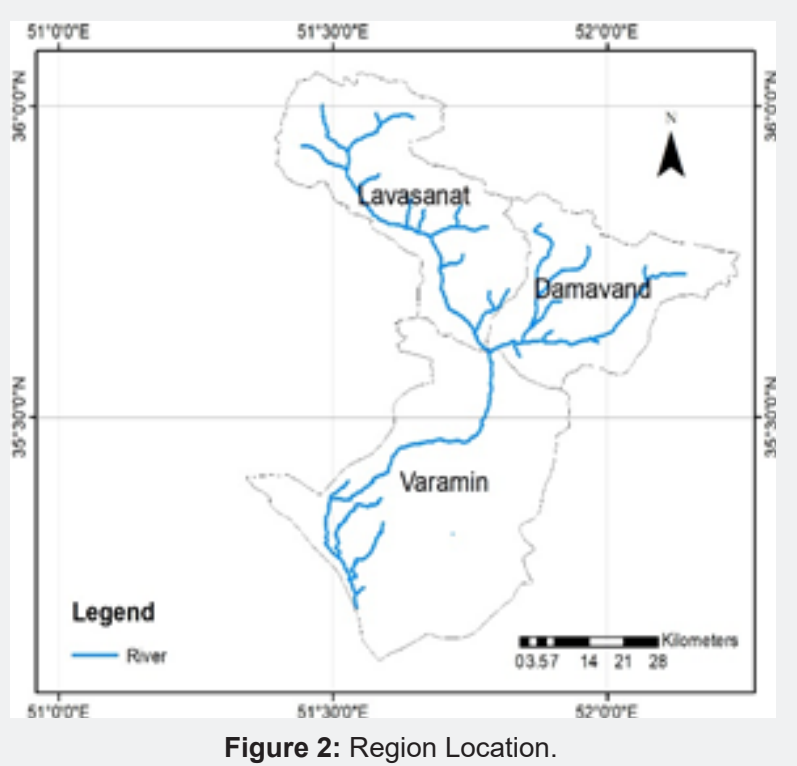

Lavasanat basin $\left(983 \mathrm{~km}^{2}\right)$ is a Salt Lake sub-basin located at geographical coordinates of $35^{\circ} 45^{\prime}$ to $36^{\circ} 5^{\prime} \mathrm{N}, 54^{\circ} 50^{\prime}$ to $51^{\circ} 20^{\prime}$ and $51^{\circ} 58^{\prime} \mathrm{E}$, with an average annual temperature of $13.5^{\circ} \mathrm{C}$. July and January are the warmest and coldest months with mean temperatures of 26.2 and $-0.8{ }^{\circ} \mathrm{C}$, respectively. Here, the annual precipitation reaches an average level of $187 \mathrm{~mm}$. August is the driest month with a mean precipitation of $<1 \mathrm{~mm}$, while precipitation is maximum in March with $32 \mathrm{~mm}$ on average. Damavand basin $\left(766 \mathrm{~km}^{2}\right)$ is another Salt Lake sub-basin situated at geographical coordinates of $35^{\circ} 33^{\prime}$ to $35^{\circ} 52^{\prime} \mathrm{N}$ and $51^{\circ} 47^{\prime}$ to $52^{\circ} 14^{\prime} \mathrm{E}$, with a mean annual temperature of $12.1^{\circ} \mathrm{C}$. July and January are the warmest and coldest months with mean temperatures of 25.3 and $-2.4{ }^{\circ} \mathrm{C}$, respectively. The annual precipitation amounts to an average of $149 \mathrm{~mm}$. August with a mean precipitation of $<1 \mathrm{~mm}$ is the driest month, while the maximum average precipitation of $32 \mathrm{~mm}$ occurs in March. As another Salt Lake sub-basin, Varamin basin $\left(1720 \mathrm{~km}^{2}\right)$ is located at geographical coordinates of $35^{\circ} 7^{\prime}$ to $35^{\circ}$ $39^{\prime} \mathrm{N}$ and $51^{\circ} 26^{\prime}$ to $51^{\circ} 55^{\prime} \mathrm{E}$, with a mean annual temperature of $16.9{ }^{\circ} \mathrm{C}$. The warmest and coldest months are July and January with average temperatures of 29.5 and $-3.3{ }^{\circ} \mathrm{C}$, respectively. The annual precipitation averages an amount of $149 \mathrm{~mm}$. The driest month is August with a mean precipitation of $<1 \mathrm{~mm}$, while the maximum average precipitation of $32 \mathrm{~mm}$ happens in March. The Jajrod, Kandrod-Galandook, Damavand, and Ah Rivers are in the study basin, the most important of which is Jajrod wherein Latian Dam is constructed in its upstream.

\section{Data}

In this study, SWAT hydrological model was developed using a 30m Digital Elevation Model (DEM) layer, land use layer of 2010, and FAO v2 soil layer with $10 \mathrm{~km}$ dimensions (Figure 3-5). In the first phase of modelling, the basin was divided into some sub-basins based on topography and dividing line network in ArcGIS environment. Then, each sub-basin was divided into some hydrological response units (HRUs) according to land use features, soil profile, and slope. The studied basin was totally divided into 68 sub-basins and 257HRUs.

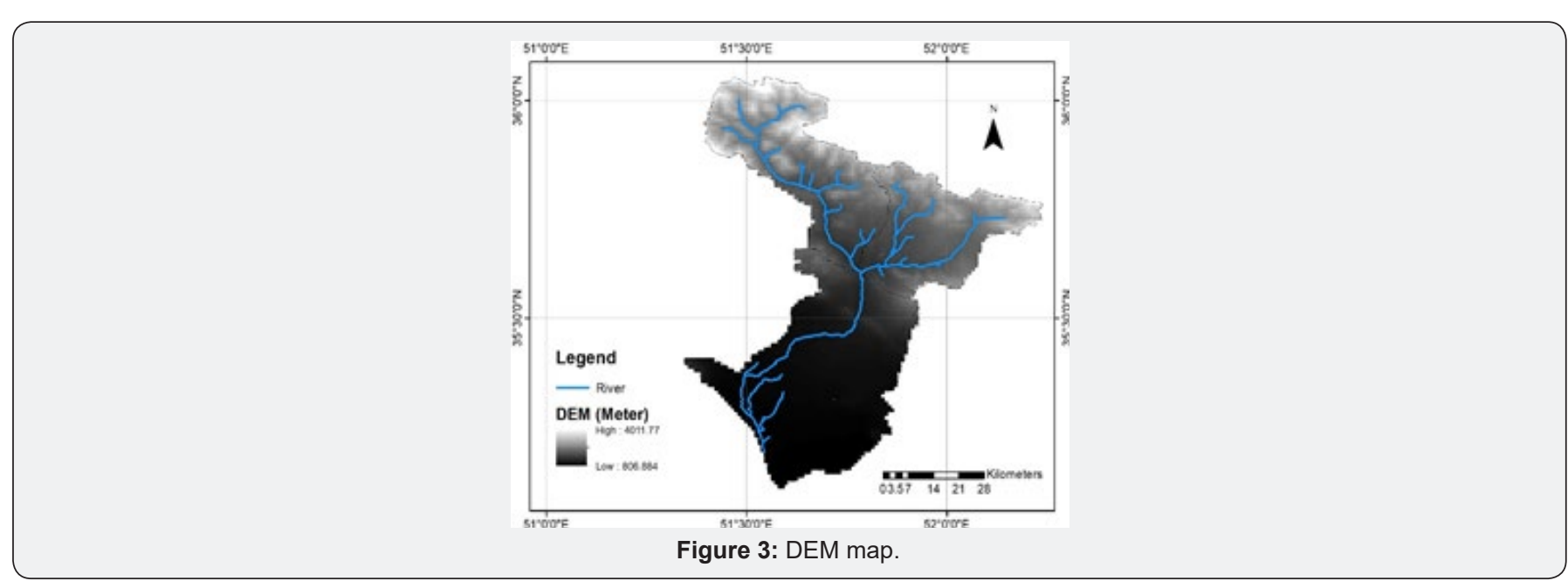




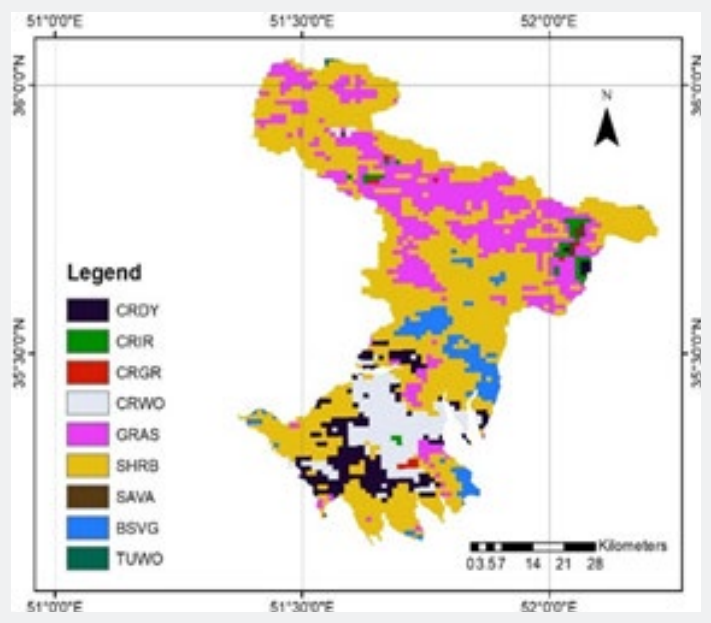

Figure 4: Land Use Map.

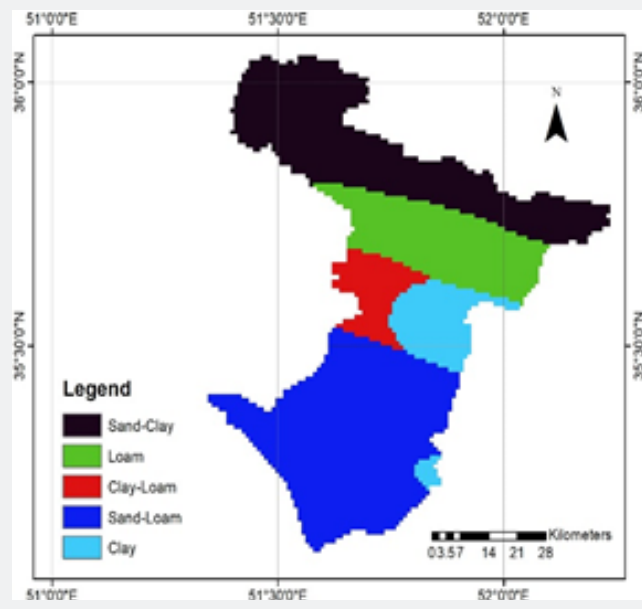

Figure 5: Soil Map.

Daily data of minimum and maximum temperatures as well as precipitation from three meteorological stations were introduced into the model to simulate the processes of interest for the period 1986-2014 using SWAT software (Ver. 2012) as a program in ArcGIS 10.2 software. The model was then calibrated and validat-

Table 1: Meteorological stations.

\begin{tabular}{|c|c|c|}
\hline Station & Latitude & Height \\
\hline Varamin & $35^{\circ} 19^{\prime} 00^{\prime \prime}$ & 915 \\
\hline Dushan Tappe & $35^{\circ} 42^{\prime} 00^{\prime \prime}$ & 1220 \\
\hline Garmsar & $35^{\circ} 14^{\prime} 00^{\prime \prime}$ & 899.9 \\
\hline
\end{tabular}

Table 2: Meteorological stations.

\begin{tabular}{|c|c|c|c|c|}
\hline Station & Station Code & Height & Longitude & Latitude \\
\hline Latian & 41119 & 1534 & $51^{\circ} 41^{\prime} 07^{\prime \prime}$ & $34^{\circ} 46^{\prime} 32^{\prime \prime}$ \\
\hline Najar kola & 41159 & 1678 & $51^{\circ} 38^{\prime} 13^{\prime \prime}$ & $35^{\circ} 49^{\prime} 30^{\prime \prime}$ \\
\hline Zar Dare & 41870 & 1415 & $51^{\circ} 53^{\prime} 03^{\prime \prime}$ & $35^{\circ} 37^{\prime} 21^{\prime \prime}$ \\
\hline Rodehen & 41929 & 1844 & $51^{\circ} 55^{\prime} 45^{\prime \prime}$ & $35^{\circ} 44^{\prime} 16^{\prime \prime}$ \\
\hline
\end{tabular}




\section{Monthly Climatic Scenarios Generated using AOGCM Models}

Coupled three-dimensional Atmosphere-Ocean Global Circulation Models (AOGCM) are currently the most reliable tools for the generation of climate scenarios [15]. These models are based on physical relationships expressed by mathematical equations, which are solved in a three-dimensional network on the globe. To simulate the global climate, the main components of the climate system (atmosphere, lithosphere, biosphere, and hydrosphere) are coupled in separate secondary models to form AOGCM models [16]. The first series of emission scenarios called IS92a-IS92f was presented by IPCC in 1992, which indicated increasing concentrations of greenhouse gases at a constant rate until 2100. In a special report, IPCC (1996) offered an updated series of emission scenarios called SRES (Special Report on Emission Scenario). The report contains 40 scenarios for the world future divided into four main groups or scenario families (A1, A2, B1, and B2) based on economic-social advancements, accumulation of greenhouse gases, and suspended particles [17].

LARS-WG is a model for generation of random climate data applied for daily precipitation production, radiation, as well as maximum and minimum daily temperatures in a station under present and future climate conditions [18-20]. The first version of LARS-WG was developed in Budapest, Hungary (1990), as a means of statistical downscaling. A random climate generator employs daily meteorological data recorded in a station to compute a series of parameters for probability distributions of meteorological variables along with their interrelationships.

\section{River flow simulation}

SWAT is a continuous model on the basin scale designed to project the impacts of various management strategies on water levels, sediments, and chemical-agricultural substances on vast and complex basins with different soil, land use, management, and morphological conditions in the long term. It is a physical-distributional model for assessing soil and water issues.

SWAT model uses water yield equation (Eq. 1) to simulate the hydrological cycle. The simulated hydrological processes involve evapotranspiration, runoff, snowmelt, surface seepage, deep seepage, groundwater flow, and subsurface flows.
In this research, HRUs are first formed and then divided by introducing the above maps. Thereafter, the parameters related to each main component called vegetation (DAT), edaphic (Sol), groundwater (GW), management (Mgt), and riverine (Rte) are introduced into the model.

$$
S W_{t}=S W_{0}+\sum_{i=1}^{t}\left(R_{\text {day }}-Q_{\text {surf }}-E_{a}-W_{\text {seep }}-Q_{g w}\right)
$$

$\mathrm{SW}_{\mathrm{t}}$ : final soil water content on day $\mathrm{t}, \mathrm{SW}_{\mathrm{t}}$ : initial soil water content, $\mathrm{T}$ : time (days), $\mathrm{R}_{\text {day }}$ : precipitation rate on day $\mathrm{t}, \mathrm{Q}_{\text {surf }}$ : runoff level on day $t, E_{a}$ : evapotranspiration on day $i, W_{\text {seep }}$ : water seepage from root zone on day $i$, and $\mathrm{Q}_{\mathrm{gw}}$ : returned flow on day $\mathrm{i}$.

\section{SWAT Sensitivity and Calibration Analysis}

As there are many parameters in SWAT model and due to concurrent simulation of many hydrological and agricultural variables in this model, a new model called SWAT-CUP has been developed to analyze its sensitivity and calibration. There are two analyses including local sensitivity, or a parameter in a time, and global sensitivity. In local sensitivity analysis, one input is changed within predefined limits while keeping other inputs constant. Then the model output changes are examined depending on changes in each parameter. The parameter with a higher absolute value of $\mathrm{t}$-stat and a p-value close to zero will have a greater effect on the variable. The model is calibrated by coefficient of determination $\left(\mathrm{R}^{2}\right)$ and NS coefficient.

\section{Results}

\section{Drought severity}

In order to investigate the drought phenomenon and its severity, the 12-month SPI index was calculated. In years when the SPI number is less than zero, there is drought while, in those years when this number is higher than one, it is a mild period. As displayed in Figure 6, the largest mild period is 5 years. Since 2008, relatively severe droughts have occurred in the plain of Varamin. Since 2013 onwards, the drought became very severe during this period, and the SPI index reached the value of -1 . In 2015, this figure was -1.31, and in 2016, the SPI index was lower than -2 . The greatest drought had happened in the base year of 1997 with the SPI index of -3 . On the other hand, the best mild period was in 1996 with an index over +2 .

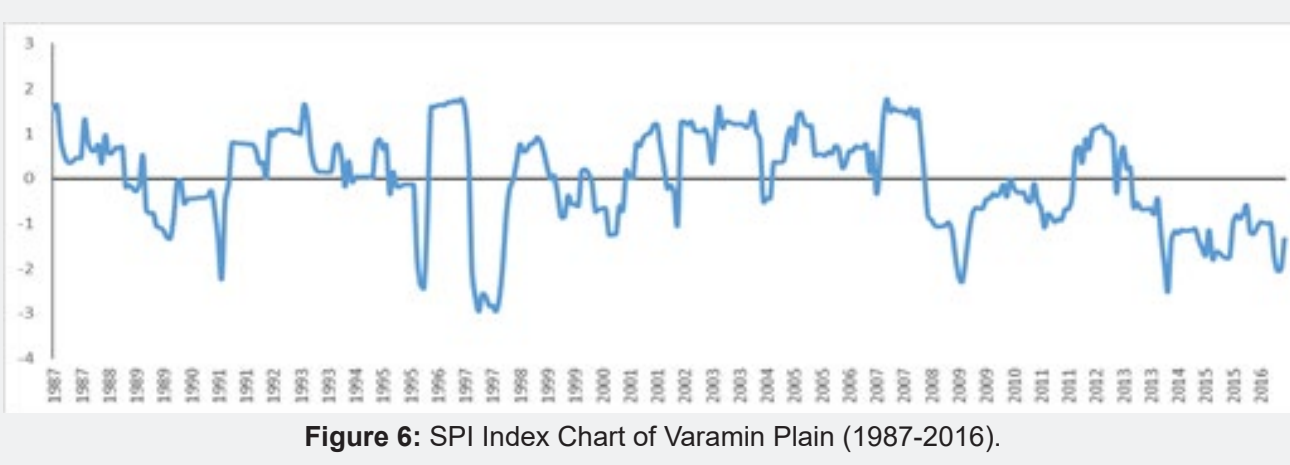




\section{Ecology \& Conservation Science: Open Access}

\section{Generation of daily climate scenarios}

The results of chi-square test and P-values for probability distributions of precipitation, as well as minimum and maximum measured and estimated temperatures across all months have been acceptable at a significance level of $1 \%$. Accordingly, LARSWG can be concluded to be capable of simulating precipitation variables and climatological station temperatures in the study area. Comparison of two statistical files revealed no significant differences between measured climatic parameters in the baseline period of 1986-2016 and those simulated by LARS-WG model. Thus, precipitation, as well as minimum and maximum temperatures in the studied station were forecasted in most A1B, A2, and B1 scenarios for the periods 2011-2030, 2046-2065, and 20802099. Table $3 \& 4$ provide the monthly changes in long-term time series, along with the average results of precipitation and temperature variables in future periods compared to the measured period, respectively $[1,17]$.

Table 3: Predicted Yield of Agricultural Products in Future Periods under Climate Scenarios.

\begin{tabular}{|c|c|c|c|c|}
\hline Scenario & Period & Irrigated Crops & Rainfed Crops & Horticultural Products \\
\hline \multirow{3}{*}{ A1B } & $2011-2030$ & 4 & 1.1 & 9.7 \\
\cline { 2 - 5 } & 20462065 & 4.1 & 1.2 & 9.8 \\
\cline { 2 - 5 } & $2080-2099$ & 3.9 & 1.1 & 9.5 \\
\hline \multirow{3}{*}{ A2 } & $2011-2030$ & 4 & 1.3 & 9.6 \\
\cline { 2 - 5 } & 20462065 & 4.2 & 1.5 & 9.9 \\
\cline { 2 - 5 } & $2080-2099$ & 4.1 & 1.2 & 9.2 \\
\cline { 2 - 5 } & $2011-2030$ & 4.1 & 1.1 & 9.2 \\
\cline { 2 - 5 } & 20462065 & 4 & 1.2 & 9.4 \\
\hline
\end{tabular}

Table 4: Estimated Yield of Representative Crops under Climatic Scenarios and Comparison with Base Period.

\begin{tabular}{|c|c|c|c|c|c|}
\hline Scenario & Period & Wheat & Barley & Alfalfa & Horticultural Products \\
\hline \multicolumn{2}{|c|}{ Base } & 5.2 & 4.9 & 5.1 & 6.5 \\
\hline \multirow{3}{*}{$\mathrm{A} 1 \mathrm{~B}$} & $2011-2030$ & 5.2 & 4.87 & 5.12 & 6.8 \\
\hline & $2046-2065$ & 5.1 & 4.81 & 5.19 & 6.77 \\
\hline & $2080-2099$ & 5.1 & 4.78 & 5.15 & 6.6 \\
\hline \multirow{3}{*}{$\mathrm{A} 2$} & $2011-2030$ & 5.32 & 4.88 & 5.1 & 6.51 \\
\hline & $2046-2065$ & 5.24 & 4.98 & 5.3 & 6.21 \\
\hline & 2080-2099 & 4.95 & 4.68 & 5.16 & 6.25 \\
\hline \multirow{3}{*}{ B1 } & $2011-2030$ & 5.33 & 4.9 & 5.21 & 6.54 \\
\hline & $2046-2065$ & 5.29 & 4.85 & 5.2 & 6.55 \\
\hline & $2080-2099$ & 5.22 & 4.84 & 5.1 & 6.44 \\
\hline
\end{tabular}

As projected by LARS-WG model, the minimum temperatures will rise in all months; also, the maximum temperatures will also grow across all months, except in February and October, during the statistical period 2011-2030. Period 2080-2099 and A2 scenario will have the greatest rises in the minimum and maximum temperatures. Growing temperature will be associated with the Table 5: Sensitivity Analysis and Determining the Effective Parameters of the Model.

\begin{tabular}{|c|c|c|c|}
\hline Parameter Name & Parameter Definition & t-Stat & P-Value \\
\hline R__CN2.mgt & Scs runoff curve number & -23.99 & 0 \\
\hline V_PLAPS.sub & Precipitation lapse rate(mm/km) & 20.84 & 0 \\
\hline R_SOL_BD (...).sol & Moist bulk density (mg/m3) & 3.92 & 0 \\
\hline V_CH_N2.rte & Manning's n value for main channel & -3.8 & 0.06 \\
\hline V_ALPHA_BF.gw & Base flow alpha factor (days) & 1.92 & 0.06 \\
\hline V_HRU_SLP.hru & Average slope steepness (m/m) & 1.92 & 0.06 \\
\hline V__LAT_TIME.hru & Lateral flow travel time (days) & -1.88 & \\
\hline
\end{tabular}

most devastating effect of climate change, i.e. increasing drought in the area. Changes have occurred both in precipitation rate and in its patterns. Hence, precipitation will decline in most months, with the greatest decrease occurring in summer under A1B scenario during the period 2080-2099. 


\section{Ecology \& Conservation Science: Open Access}

\begin{tabular}{|l|c|c|c|}
\hline V_SLSUBBSN.hru & Average slope length & -1.62 & 0.11 \\
\hline V__RCHRG_DP.gw & Deep aquifer percolation fraction & 1.57 & 0.12 \\
\hline
\end{tabular}

\section{Sensitivity analysis of model parameters}

Finally, the period 1998-2014 was selected after analyzing the statistics from climatological and hydrometric stations in the studied basin and considering the research objective and the need of model for inputs with continuous time paces and simultaneous time series. Of this statistical period, the years 1998-2011 were evaluated for calibration, while three last years (2011-2014) were used to validate the model. Then, calibration and validation of SWAT model were performed through preparing monthly time series of the measured data using SWAT-CUP software and SUFI2 algorithm. A total of 103 sensitive parameters were calibrated and validated to simulate runoff in the model. Parameters with relatively greater impacts on the stream flow (discharge) are reported in Table 5 .

Phrases $\mathrm{v}$ and $\mathrm{r}$ are the codes that determine the type of changes applied to a parameter; $v$ denotes replacement of the parameter value with a new value of a new parameter, and $r$ is the parameter value multiplied by $(1+$ given value $)$ through replacing the parameter $[4,21]$.

Table 6 presents the effects of some important parameters involved in the simulation of stream flow in the sub-basins together with P-values and t-stats. The parameter with a relatively higher $\mathrm{t}$-stat absolute value and a P-value close to zero has had a greater impact on the stream flow.

Table 6: Estimation of Evapotranspiration Changes under Climate Scenarios for Future Periods (mm).

\begin{tabular}{|c|c|c|c|}
\hline Scenario & Period & Actual Evapotranspiration (ET) & Potential Evapotranspiration (PET) \\
\hline \multicolumn{2}{|c|}{ Base } & 258.37 & 2043.33 \\
\hline \multirow{3}{*}{$\mathrm{A} 1 \mathrm{~B}$} & 2011-2030 & 301.06 & 2225.73 \\
\hline & $2046-2065$ & 310.3 & 2287.75 \\
\hline & $2080-2099$ & 317.78 & 2344.95 \\
\hline \multirow{3}{*}{$\mathrm{A} 2$} & $2011-2030$ & 302.09 & 2227.94 \\
\hline & $2046-2065$ & 309.3 & 2283.08 \\
\hline & $2080-2099$ & 321.16 & 2376.23 \\
\hline \multirow{3}{*}{ B1 } & 2011-2030 & 301.3 & 2225.82 \\
\hline & $2046-2065$ & 308.55 & 2273.49 \\
\hline & $2080-2099$ & 312.97 & 2303.14 \\
\hline
\end{tabular}

\section{Calibration and validation of SWAT model}

After sensitivity analysis, the model was calibrated and validated using monthly statistics from four hydrometric stations. The model simulations were evaluated by coefficient of determi- nation $\left(\mathrm{R}^{2}\right)$ and NS coefficient (Table 7). Despite the vastness of the basin, the final calibration values indicated the ability of SWAT model in simulating the basin. Figure 7 display the measured and simulated time series of stream flow with $95 \%$ confidence level for Latian station.

Table 7: Calibration and Validation Results for each Hydrometric Station in the Period 1987-2014.

\begin{tabular}{|c|c|c|c|c|c|c|}
\hline \multirow{2}{*}{ Station } & River & Station Code & $\mathbf{R}^{2}$ & \multicolumn{2}{|c|}{ NS } & \multicolumn{2}{|c|}{ Calibration } \\
\cline { 3 - 7 } & & & \multicolumn{2}{|c|}{ Validation } \\
\hline Latian & Jajrod & 41119 & 0.65 & 0.58 & 0.5 \\
\hline Najarkola & Kandroud- Galandook & 41159 & 0.67 & 0.57 & 0.54 \\
\hline Zar Dareh & Damavand & 41870 & 0.64 & 0.6 & 0.55 \\
\hline Rodehen & Ah & 41929 & 0.61 & 0.49 & 0.58 \\
\hline
\end{tabular}

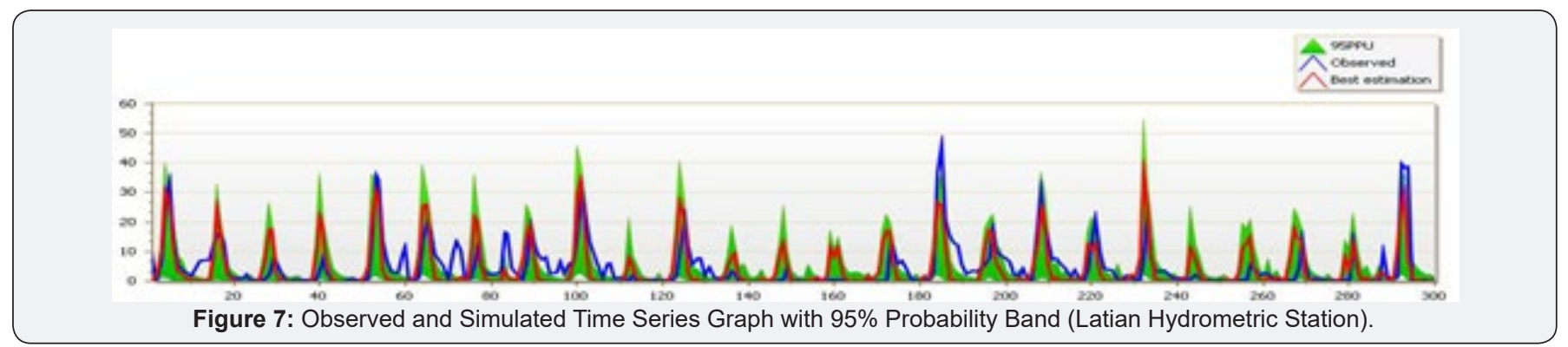




\section{Ecology \& Conservation Science: Open Access}

\section{Simulation of runoff influenced by climate change}

As SWAT model needs both parameters at the same time, HadCM3 has been introduced as the selected model whose data have been applied in all phases. The scenarios have been selected based on drawing future climate conditions. Accordingly, A1B draws a temperate weather, A2 presents the most critical condition in parameter estimation, and B1 provides more optimistic consequences than the other two scenarios under climate change impact.
Following LARS-assisted downscaling of climate data for future periods under the above scenarios and HadCM3 model, a 30-year time series of the data for all three future periods was prepared to be introduced into SWAT model. Afterwards, SWAT output with the applied coefficients was analyzed by SWAT-CUP, and monthly runoff level was simulated based on the baseline period duration for future periods under $\mathrm{A} 1 \mathrm{~B}, \mathrm{~A} 2$, and $\mathrm{B} 1$ scenarios. Figure 8 illustrate climate change effects on the mean monthly runoff levels for Latian station.

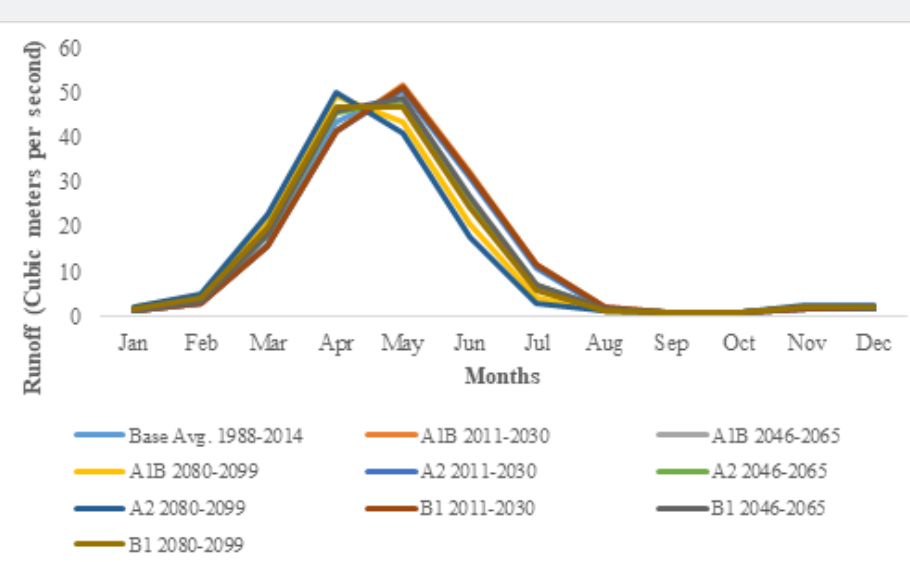

Figure 8: Observed and Simulated Time Series Graph with 95\% Probability Band (Latian Hydrometric Station).

As displayed in Figure 8, the stream flow curves for future periods under all three scenarios are shifted rightward compared to the baseline period suggesting ascending and descending runoff levels in winter, as well as in summer and spring, respectively. Such a shift results from climate change impacts (snowmelt, altered precipitation pattern, etc.) on the basin runoff. Among the hydrometric stations, that of Latian Dam presented the minimum runoff level. According to the results, runoff will increase in spring and summer, but it will drop in fall and winter during the period 2011-2030 under all three climate scenarios. During periods 2046-2065 and 2080-2099, however, runoff will diminish in spring and summer, but it will rise in fall and winter under all three climate scenarios. The minimum and maximum runoff levels happen during 2080-2099 period under A2 scenario in summer and winter, respectively.

\section{Evapotranspiration influenced by climate change}

As represented in Table 6, both actual and potential evapotranspiration were simulated for future periods under climate scenarios and compared with the baseline period. Accordingly, both future-period actual and potential evapotranspiration show a rising trend with the potential evapotranspiration being always higher than actual values. Evapotranspiration is maximum during 2080-2099 period under A2 scenario.

\section{Simulation of crop yield}

The representative crops including wheat, barley, and alfalfa were introduced to SWAT model. Then, the mean crop yields were simulated in years without water tension for average amounts of 4t/ha (irrigated) and 1.2t/ha (rainfed) crops.

The mean crop yields are 3.7t/ha and 1.8t/ha for irrigated and rainfed crops, respectively. In the areas under investigation, major horticultural products are cherry, walnut, pomegranate, and olive, all of which were introduced to SWAT model. Based on the reports by the Energy and Agriculture Jihad ministries, the average yields of these products have been recorded as $9.8 \mathrm{t} / \mathrm{ha}$. SWAT model simulated an average yield of $9.5 \mathrm{t} /$ ha in years without water tension. According to our findings and the high accuracy of SWAT model in simulating crop yields, it can be used for crop yield simulation in future periods. Table 7 outlines the simulation of crop yields for future periods under A1, B2, and A1B climate scenarios.

As seen in the table, agronomical and horticultural products in the surveyed basin have not undergone considerable changes compared to the baseline period given the use of groundwater for irrigation of crops. This is because irrigation by groundwater is always constant and not dependent upon surface water and precipitation. Basin feeding by precipitation has been reported to be less than 7\%. Also, SWAT model considers groundwater as a reservoir containing water forever. As displayed in Figure 7 no visible changes have been practically seen in the crop yields irrigated with groundwater.

\section{Conclusion}

This study examined climate change impact on the surveyed basin runoff during periods 2011-2030, 2046-2065, and 20802099 using statistical (LARS-WG) and conceptual hydrological 


\section{Ecology \& Conservation Science: Open Access}

(SWAT) models under A1B, A2, and B1 emission scenarios. Variations in precipitation and temperature were analyzed as two climate-introducing variables. According to the table, the mean downscaled results of the baseline period shifted rightwards suggesting ascending and descending runoff levels in winter, as well as in summer and spring, respectively. Such a shift results from climate change impacts (snowmelt, altered precipitation pattern, etc.) on the basin runoff. An increase in spring runoff can be caused by temperature rise, snowmelt, altered precipitation pattern, and other factors. Ascending temperatures will be associated with the most detrimental effect of climate change, i.e. increasing drought in the area. Negative effects of rising temperature on water resources is exacerbated by evaporation leading to lowered quantity and quality of water resources. Future-period evapotranspiration will grow under all three scenarios with adverse consequences on water resources of the area. Diminishing precipitation in future periods will lead to reductions in rainfed crop yields. However, since both agronomical and horticultural products are irrigated by groundwater, climate change will not affect the yields of such crops considerably. It is recommended that land use alterations are also studied together with climate change in future investigations.

\section{References}

1. Solomon SD, Qin M, Manning Z, Chen M, Marquis KB, et al. (2007) IPCC. Summary for Policy makers, in: Climate Change, Climate Change. The Physical Science Basis. Contribution of Working Group I to the Fourth Assessment Report of the Intergovernmental Panel on Climate Change, Cambridge University Press.

2. Harmsen E, Miller NL, Schlegel NJ, Gonzalez JE (2009) Seasonal Climate Change impacts on evapotranspiration, precipitation deficit and crop yield in Puerto Rico. Agricultural Water Management 96(7): 1085-1095

3. Alipour A, Hashemi M, Pazhooh F, Naserzadeh MH (2017) Recognize and compare Iran's Deserts from the Aspect of Geomorphology and Climatology (case study: Iran's east and central areas desert). Iranian Journal of Eco Hydrology 7(27): 21-34.

4. Xu CH (1999) From GCMs to river flow: A review of downscaling methods and hydrologic modelling approaches. Physical Geography: Earth and Environment 23(2): 229-249.

5. Ficklin DL, Lou Y, Luedeling E, Gatzke SE, Zhang M (2010) Sensitivity of agricultural runoff loads to rising levels of $\mathrm{CO}_{2}$ and climate change in the San Joaquin Valley watershed of California. Environ. Pollut 158(1): 223-234.

6. Devkota LP, Gyawali DR (2015) Impacts of climate change on hydrological regime and water resources management of the Koshi River Basin, Nepal. Journal of Hydrology 4: 502-515.
7. Besalatpour AA, Ayoubi Sh, Hajabbasi MA, Jalalian A (2015) Calibration and Validation of SWAT model using PSO algorithm for the simulation of runoff and sediment in a mountainous watershed with limited climate data. Journal of Soil Management and Sustainable 4(4): 295312.

8. Shrestha B, Cochrane TA, Caruso BS, Arias ME, Piman T (2016) Uncertainty in flow and sediment projections due to future climate scenarios for the 3S Rivers in the Mekong Basin. Journal of Hydrology 540: 1088-1104.

9. Kishiwa P, Nobert J, Kongo V, Ndomba P (2018) Assessment of impacts of climate change on surface water availability using coupled SWAT and WEAP models: case of upper Pangani River Basin, Tanzania. International Association of Hydrological Sciences 378: 23-27.

10. Zhou Y, Lai Ch, Wang Zh, Chen X, Zeng Zh (2018) Quantitative Evaluation of the Impact of Climate Change and Human Activity on Runoff Change in the Dongjiang River Basin, China. Water 571: 1-17.

11. Yin J, Yuan Zh, Yan D, Yang Zh, Wang Y (2018) Addressing Climate Change Impacts on Streamflow in the Jinsha River Basin Based on CMIP5 Climate Models. Water 910: 1-19.

12. Daba M (2018) Sensitivity of SWAT Simulated Runoff to Temperature and Rainfall in the Upper Awash Sab-Basin, Ethiopia. Hydrology Current Research 9(1): 1-7.

13. Al Qatarneh GN, Al Smadi B, Al-Zboon K, Shatanawi KM (2018) Impact of Climate Change on water resources in Jordan: a case study of Azraq basin. Applied Water Science 50: 1-14.

14. Hajimohammadi M, Azizian A, Ghermezcheshmeh B (2018) Evaluation of the impact of climate change on runoff Kan Watershed. Watershed Engineering and Management 10(2): 144-156.

15. Wilby RL, Harris I (2006) A frame work for assessing uncertainties in climate change impacts: low flow scenarios for the River Thames, UK. Water Resources Research 42(2): 1-10.

16.Zarezadeh MM (2011) Water allocation in Ghezel-Ozan Basin under climate change using bankrupting in conflict resolution. Dissertation, Tarbiat Modares University.

17. IPCC, Climate change (2001) The science of climate change. Contribution of working group I to the second assessment report of the intergovernmental panel on climate change,eds. Cambridge University Press, Cambridge.

18. Rasco P, Szeidl L, Semenov MA (1991) A Serial approach to local stochastic models. Ecological Modeling 57(1-2): 27-4.

19. Semenov MA, Brooks RJ, Barrow EM, Richardson CW (1998) Comparison of the WGEN and Stochastic weather generators in diver's climates, Climate Research 10: 95-107.

20. Semenov MA, Barrow EM (2002) A Stochastic weather generator for use in climate impacts studies. User's manual. Version 3.0.

21. Yang M, Xiao W, Zhao Y, Li X, Huang Y, et al. (2018) Assessment of Potential Climate Change Effects on the Rice Yield and Water Footprint in the Nanliujiang Catchment, China. Sustainability 242: 1-19. 
This work is licensed under Creative Commons Attribution 4.0 License DOI: 10.19080/ECOA.2019.01.555559
Your next submission with Juniper Publishers will reach you the below assets

- Quality Editorial service

- Swift Peer Review

- Reprints availability

- E-prints Service

- Manuscript Podcast for convenient understanding

- Global attainment for your research

- Manuscript accessibility in different formats (Pdf, E-pub, Full Text, Audio)

- Unceasing customer service

Track the below URL for one-step submission https://juniperpublishers.com/online-submission.php 